\title{
Characteristics and coastal effects of a destructive marine storm in the Gulf of Naples (Southern Italy)
}

\author{
Gaia Mattei ${ }^{1}$, Diana Di Luccio ${ }^{1}$, Guido Benassai ${ }^{2}$, Giorgio Anfuso ${ }^{3}$, Giorgio Budillon ${ }^{1}$, and \\ Pietro Aucelli ${ }^{1}$ \\ ${ }^{1}$ Department of Science and Technologies, University of Naples “Parthenope”, Naples 80100, Italy \\ ${ }^{2}$ Department od Engineering, University of Naples "Parthenope", Naples 80100, Italy \\ ${ }^{3}$ Departamento de Ciencias de la Tierra, Facultad de Ciencias del Mar y Ambientales, Universidad de Cádiz, Puerto Real \\ 11510, Cádiz, Spain
}

Correspondence: Diana Di Luccio (diana.diluccio@uniparthenope.it)

\begin{abstract}
Destructive marine storm bring large waves and unusually high surges of water to coastal areas, resulting in significant damages and economic loss. In this study it is examined the characteristics of a destructive marine storm on the strongly inhabited coastal area of Naples Gulf, along the Italian coasts of the Tyrrhenian Sea, which is highly vulnerable to marine storms due to the accelerated relative sea level rise trend and the increased anthropogenic impact on the coastal area. The marine storm, occurred on the 28th December 2020, was analysed through an unstructured wind-wave coupled model that takes into account the main weather-marine components of the coastal setup. The model, validated with in-situ data allowed to establish threshold values for the most significant marine and atmospheric parameters (i.e., wind intensity and duration) beyond which an event can produce destructive effects. Finally, a first assessment of the return period of this event was evaluated using local press reports on damage on urban furniture and port infrastructures.
\end{abstract}

\section{Introduction}

Impacts of storms on coastal areas induce relevant economic and human losses that demand a better knowledge of coastal exposure and oblige to reflect on the adoption of measures to reduce the impacts of these events (Costas et al., 2015). The erosive effects on the coasts of these processes are controlled by the interplay between storm characteristics and coastal geomorphology (Lionello and Scarascia, 2020). Moreover, coastal damage, strongly related to storm-induced processes (i.e. flooding or erosion), can be exacerbated by the presence of intensive human activities or other developments in residential localities as ports or touristic infrastructures (Godschalk et al., 2000; Esnard et al., 2001; Jiménez et al., 2012).

Storm impact assessment on urbanized coastal areas in the Mediterranean Sea (Sanuy et al., 2018; Lira-Loarca et al., 2020; Amores et al., 2020; Cavaleri et al., 2019; Jiménez et al., 2018; Amarouche et al., 2020) has become an issue of high scientific and social interest due to the alarming effects related to the climate changes observed over the last decades (Young and Ribal, 2019; Lionello and Scarascia, 2020; Gulev and Grigorieva, 2004), not only in the form of an increasing trend in significant wave heights $\left(H_{s}\right)$ and wind speed $\left(W_{s}\right)$ (Dobrynin et al., 2012; Reguero et al., 2019; Vieira et al., 2020; Meucci et al., 2020), but also due to the accelerated relative sea level rise. 
The examination of the behaviour, evolution and consequences of the coastal storm disasters is necessary to assess their danger and the population's ability to adapt and mitigate their effects (Tsai and Chen, 2011). In this respect many Authors (Van Westen, 2013) recognized the relevance of a risk analysis based on its estimation, identification and understanding.

To this aim, this paper deals with the characterization of a significant storm occurred in the Gulf of Naples (Italy) that was reconstructed by analysing weather and marine data obtained from in-situ instruments and numerical simulations.

The study area exhibits a seasonal wave climate as observed along the whole coastal area of the Tyrrhenian Sea (Morucci et al., 2016; Saviano et al., 2020). Low $H_{s}$ (in the order of a few tens of centimeters) are measured during the summer (from June to August) and significant waves up to $3 \mathrm{~m}$ during winter and autumn (from November to February). However, coastal effects of the most intense winter events on a specific coastal sector not only depend on wave height and period, but also on storm groupiness and interaction of the storm waves with respect to the bathymetry and the shoreline. Consequently, a precise assessment of the parameters that characterize a storm event is a significant challenge to better understand final effects on the coast associated with potential damages (Biolchi et al., 2019; Ferrando et al., 2021; Anfuso et al., 2016).

Therefore this paper focuses on defining and interpreting the dangerousness of the extreme storm waves that occurred in the Gulf of Naples on 28th December 2020. The storm intensity was analysed on the basis of historical weather-marine data coupled with the spatial modelling of barometric pressure, wind speed, and wave height and direction. This severe event strongly impacted the coast of Naples city, flooded wide areas and greatly damaged the promenade and restaurants, although the significant wave height measured by the wave buoy in the Gulf not exceeded $3.5 \mathrm{~m}$. The examination of the duration, degree of severity, assessment of damages and losses, reported in the local press, were compared with those of local historical chronicles, in order to demonstrate its high return period. The numerical assessment of the storm surge on the most impacted coastal sector was carried out by means of an expeditive procedure, validated with in-situ data, which took into account the main weather-marine components of the coastal setup. The aim of this paper was twofold: on one hand to characterize the event, by applying a large-scale evaluation of the weather-marine variability during the maximum peak; on the other, to define a fast procedure able to establish threshold values for the most significant marine and atmospheric parameters (i.e. wind intensity and duration), beyond which an event can produce destructive effects on human activities and coastal infrastructures. This procedure, coupled with the high-precision marine-weather forecasting, provided by the network in the Gulf of Naples belonging to University of Naples "Parthenope", might be intended as a tool for civil protection and coastal damage prevention purposes. The approach proposed in this study can be efficiently used to define the level of sensitivity of urbanized coasts to storms (Williams et al., 2018; Molina et al., 2019, 2020).

The paper is organized as follows: Section i.Introduces the thematic, Section ii. details the study area characteristics, Section iii. describes the methodologies, Section iv. presents the reconstruction of the storm event on the framework of historical wind events, Section v. discusses the coastal effect of the storm surge, and Section vi. concludes. 


\section{Study area}

The Naples Gulf (Figure 1), Tyrrhenian Sea, is one of the most populated Italian areas, with 3,016,762 inhabitants and a medium density of 2,672 inhabitant $/ \mathrm{km}^{2}$. The urban territory includes 92 municipalities on a surface of $1,171 \mathrm{~km}^{2}$, with a $60 \%$ of small municipalities (surface $<10 \mathrm{~km}^{2}$ ) and an $11 \%$ of big ones (surface $>25 \mathrm{~km}^{2}$ ). The lasts include the coastal cities of Naples, Torre Annunziata and Pozzuoli. The urbanized area in the Gulf occupies only the $32.54 \%$ of the total surface, and consequently the population density in this area is more than 8,000 inhabitant $/ \mathrm{km}^{2}$. Under these circumstances, the urbanized coasts of the Gulf can be certainly considered highly sensitive from both a social and economic point of view to severe marine storms. On the other hand, main cities are located in narrow coastal plains, with commercial activities and infrastructures located only few meters above sea level (Ascione et al., 2020). In fact, the present coastal morphology in the Gulf (Figure 1) is characterized by an alternation of articulated seacliffs with sheltered pocket beaches, and narrow coastal plains, often strongly urbanized (Ascione et al., 2020; Aucelli et al., 2017). In particular, the high-coastal sectors in the Gulf can be divided in seacliffs made of volcanic deposits typically bordered by wide shore platforms (often of polycyclic origin), and plunging cliffs in hard limestones located along the eastern side of the Gulf (Aucelli et al., 2016a, b; Pappone et al., 2019; Aucelli et al., 2019; Mattei et al., 2020). The main coastal plains in the Gulf, that are Fuorigrotta, Chiaia, Sebeto and Sarno plains (filled by successions of volcanoclastic deposits) host the most populated cities in the Gulf, i.e. Naples and Torre Annunziata (Romano et al., 2013; Vacchi et al., 2016; Cinque, 1991).

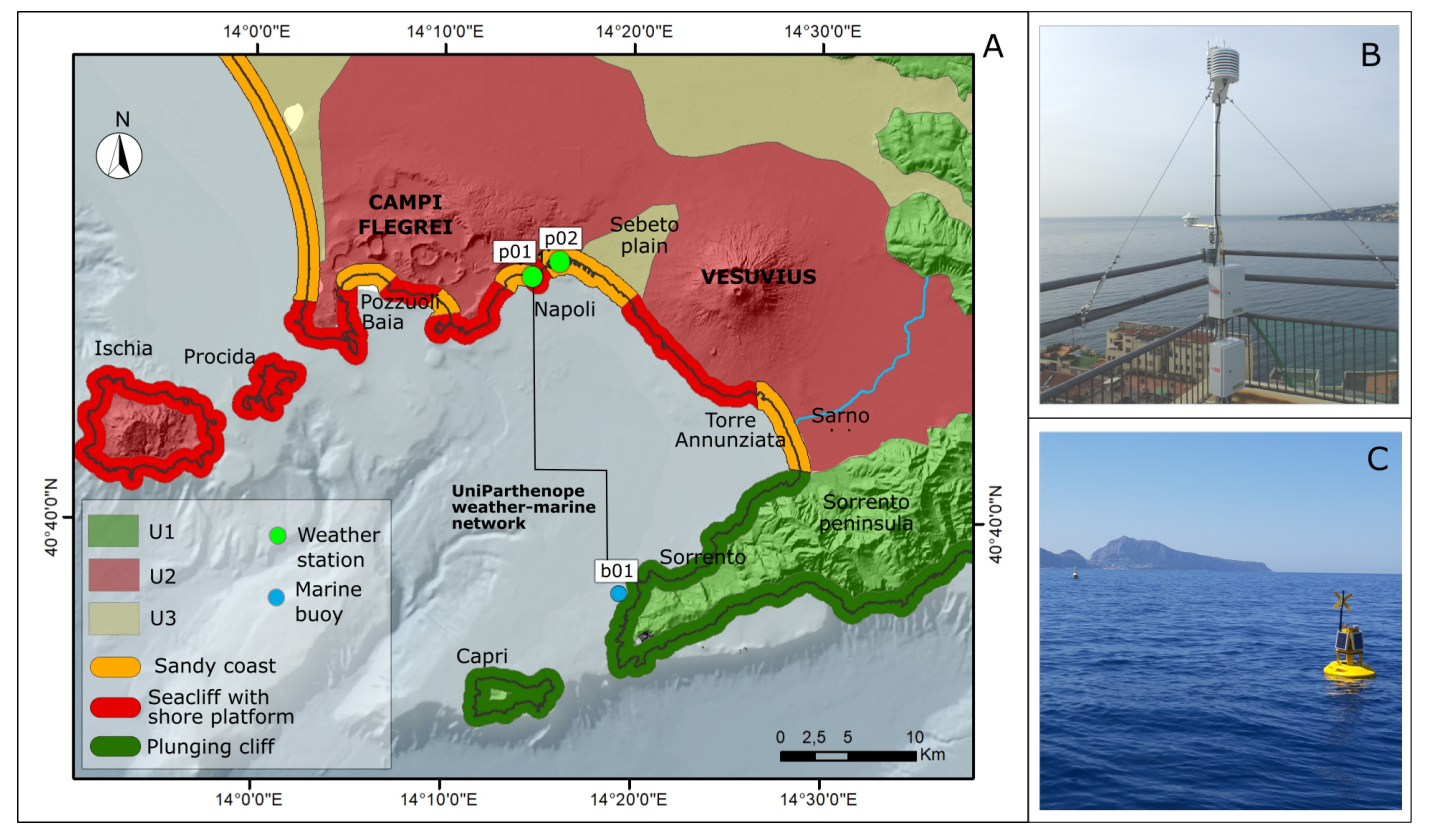

Figure 1. A) Geological and geomorphological sketch of the study area: U1 - Limestones, dolomites and marls of carbonate platform units (Meso-Cenozoic); U2 - Volcanoclastic deposits (Quaternary); U3 - Alluvial, coastal, palustine-lacustine and slope deposits (Quaternary); Pothos of the B) weather station and C) ondameter belonging to the Parthenope University network. 
From a geological point of view, the Gulf of Naples is an active peri-Tyrrhenian basin extending for about $1000 \mathrm{~km}^{2}$. It is characterized by physiographic features typical of a passive continental margin sector, with a continental shelf between -140 and $-180 \mathrm{~m}$ of depth (Milia and Torrente, 1999, 2003). The structure of the Gulf of Naples is controlled by numerous Quaternary fault systems, NE-SW trending SE-dipping and NW-SE trending SW dipping, linked to the last stages of the opening of the Tyrrhenian Sea (Fedele et al., 2015; Milia, 2010). Between the Middle and Upper Pleistocene, the fault systems were responsible for the development of the half-graben of the Gulf of Naples and Sorrento Peninsula fault block ridge (Milia and Torrente, 2003). The landscape of this area is strongly influenced by the presence of two active volcanos: the Campi Flegrei poly-caldera on the west and the Vesuvius stratovolcano on the east (Figure 1), that interfered with its Late Pleistocene - Holocene evolution (Iannace et al., 2015; Isaia et al., 2018; Santacroce et al., 2003).

During the Holocene, the morpho-evolutive trends of the coasts of the Gulf of Naples has been characterized by sudden coastal changes strongly related to the interplay between glacio-isostatic sea level rise and volcanic forcing (Cinque et al., 2011; Aucelli et al., 2020, 2019, 2018a, b; Mattei et al., 2020). The latter was driven by the combined effects of volcanic eruptions with consequent landscape mantling by pyroclastic products, and vertical ground movements of metric entity related to sudden uplift for inflating and subsidence for deflating of the magmatic chamber. Since the historical times, the anthropic impact started interfering with these natural forcing often producing permanent modifications of the original coastal landforms (Aucelli et al., 2021; Pappone et al., 2019; Mattei et al., 2018), through mining activities and construction of port structures and infilling. However, the major forcing factor to be taken into account as main cause of the recent coastal changes in the Gulf certainly is the local wave climate. In detail, main stormy events (Menna et al., 2007) with wave height values up to $4.8 \mathrm{~m}$, are associated with atmospheric low-pressure systems and occur during winter (December - February). According to Saviano et al. (2019), high-frequency radar (HFR) data shows that the highest waves mainly approach from $180^{\circ} \mathrm{N}$ to $210^{\circ} \mathrm{N}$ this confirming a marked South - West directionality, as expected from the local morphology of the Gulf.

On the contrary, in late spring and summer periods the main wind regime is represented by breezes, with SSW direction and maximum speed values of $8 \mathrm{~m} / \mathrm{s}$ (Menna et al., 2007), that produce low wave height values ranging from 0.4 to $0.6 \mathrm{~m}$ (Benassai et al., 1994; Buonocore et al., 2003; Saviano et al., 2019).

Considering the seasonal surface circulation, during winter, cyclonic and anticyclonic circulation systems alternate in the Gulf due to the interaction between the local wind forcing and the large-scale circulation of the Tyrrhenian Sea. In spring, when a shallow and sharp seasonal thermocline is present, coastal upwelling is recorded and generates internal waves that propagate along the coast causing relevant mixing processes (de Ruggiero et al., 2018). In summer, the breeze forcing induces a relatively regular diurnal current oscillation (de Ruggiero et al., 2016). In this last season, surface currents typically rotated clockwise under the effect of land and sea breeze over an entire day (Uttieri et al., 2011). In autumn, the circulation is similar to the one recorded in winter. 


\section{Materials and methods}

\subsection{Wind observations}

Data from different facilities, devoted to meteorological in situ observations, were consulted to provide an historical analysis of the wind event that affected the study area in the last ten year, and to evaluate the accuracy of the simulation results. The following weather stations located in the Naples city were considered (see Figure 1):

- p01 (14² $\left.14^{\prime} 41.78^{\prime \prime} \mathrm{E}-40^{\circ} 49^{\prime} 55.16^{\prime \prime} \mathrm{N}\right)$ is managed by the University of Naples "Parthenope" (Fig. 1a). From 2015, this Vaisala Weather Transmitter (WXT520) measures barometric pressure, humidity, precipitation, temperature, and wind speed and direction. The Vaisala WINDCAP sensor uses ultrasound to determine horizontal wind speed and direction with an accuracy of $\pm 0.3 \mathrm{~m} / \mathrm{s}$ and $\pm 3^{\circ}$, respectively.

- p02 (14 $\left.16^{\prime} 30.63^{\prime \prime} \mathrm{E}-40^{\circ} 50^{\prime} 24.46^{\prime \prime} \mathrm{N}\right)$ is part of the National Tidegauge Network, and it is managed by the Italian Institute for Environmental Protection and Research (ISPRA). The weather station is located in the port of Naples at the Diaz pier.

Considering such data bases, an analysis of wind events was applied to 2010-2020 wind records in order to evaluate and classify the storms that approached from SW in the last 10 years. Therefore, the dataset was filtered for events coming from $202^{\circ}-242^{\circ}$ directions, highlighting those with velocity higher than $13.9 \mathrm{~m} / \mathrm{s}$ (the lower limit of the "near gale" class in Beaufort scale) and duration $>6$ hours (according to Allen, 1991). Subsequently, for each of the selected events, the magnitude (M) was evaluated according to the following equation:

$M=h * v^{2}$

where $h$ is the event duration in hours and $v$ is the wind speed in $\mathrm{m} / \mathrm{s}$ (modified from Allen, 1991).

\subsection{Wave observations}

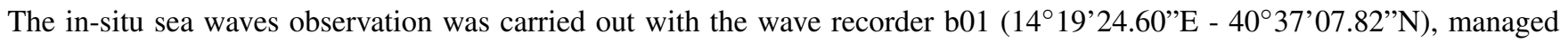
by the University of Naples "Parthenope" (Fig. 1a,c). The buoy is located in the Gulf of Naples near the Vervece islet, and it is operative since 2015. It is equipped with a BRIZO-X directional GNSS wave height sensor to record wave statistics as significant wave height $\left(H_{s}\right)$, maximum wave height $\left(H_{m}\right)$, peak wave period $\left(T_{p}\right)$, mean zero upcrossing period $\left(T_{m}\right)$, mean wave direction $\left(D_{m}\right)$, wave spread $\left(D_{s}\right)$, and wave spectra.

A subset of the dataset was used to evaluate the accuracy of the offshore wave simulations during the considered 2020December storm event. 


\subsection{Atmospheric-marine numerical workflow}

In order to characterize the meteo-marine scenario during the 2020-December storm event, an high spatial resolution model chain (Sánchez-Gallegos et al., 2021; Di Luccio et al., 2020b; Sánchez-Gallegos et al., 2019b, a) was configured using the workflow orchestrator DagOnStar (Montella et al., 2018) to manage and run the community numerical models Weather Research and Forecasting (WRF) (Skamarock et al., 2001; Powers et al., 2017) and Wavewatch III (WW3) (?).

The first workflow component is the atmospheric model WRF which computes the $10 \mathrm{~m}$ wind fields and other atmospheric parameters needed to drive the WW3 offshore wave model.

The weather pattern (e.g. $10 \mathrm{~m}$ wind field, sea level pressure, etc.) during the 2020-December storm was reconstructed with the WRF model with the following two-way nested computational domains: a coarser domain $(25 \mathrm{~km})$ covering the whole Europe, an intermediate domain $(5 \mathrm{~km})$ on Italian peninsula, and a finer domain $(1 \mathrm{~km})$ on the Southern Thyrrenian Sea. The WRF model initial condition were provided by the Global Forecast System (GFS) owned by the National Center for Environmental Prediction (NCEP).

A similar telescopic configuration was used in case of WW3 wave model with a ground resolution of $0.09^{\circ}$ on the whole Mediterranean Sea, an intermediate resolution of $0.03^{\circ}$ for seas surrounding Italy, and a finer resolution of $0.01^{\circ}$ for the southern Thyrrenian Sea. In this case, the weather conditions provided by WRF were used to drive the marine dynamic in Mediterranean Sea closed geographical domain, so no wave boundary condition was necessary. Moreover, an offline coupling approach between the atmospheric model WRF and the wave model WW3 was applied. The simulation results were provided with 1-hour timestep in NetCDF format.

This configuration of WRF and WW3 numerical models had been already tested in other applications involving, among others, the beach run-up calculation (Di Luccio et al., 2018a, 2020b), the rip-current identification (Di Luccio et al., 2018b), the reconstruction of weather (Di Luccio et al., 2020a, 2021; Montella et al., 2019; ?) and marine (Castagno et al., 2020) patterns.

150 In the present application, the simulated wind speed $\left(W S_{s}\right)$ and direction $\left(W D_{s}\right)$, the sea level pressure $\left(S L P_{s}\right)$, the significant wave height $\left(H s_{s}\right)$, and the mean wave period $\left(T m_{s}\right)$ and direction $\left(D m_{s}\right)$ were analyzed to characterize the 2020December storm along the whole Gulf of Naples, using the maximum resolution dataset available for WRF and WW3 models.

\subsection{Set-up evaluation}

The reconstruction of the main erosive effects of the maximum water level time interval $\left(t_{\max }\right)$ occurred during the 2020December storm in the study area, was performed with the following methodological steps.

1) The first step is aimed to detect the most-impacted coastal sectors in the Gulf of Naples during $t_{\max }$. To do this, each weather-marine parameter $W S_{s}, H s_{s}$ and $S L P_{s}$ was classified taking into account the 5 classes of intensity and/or impact on the coasts summarized in Table 1. Wind intensity was classified according to Beaufort scale, considering also the range of wind variability in the Gulf in the last 10 years. In particular, class 1 corresponds to fresh breeze, class 2 is strong breeze, classes 3 and 4 are near gale and class 5 is gale or higher than gale. Wave height was classified according to Douglas scale, where 


\begin{tabular}{|c|c|c|c|c|}
\hline Class & Wind speed $[\mathrm{m} / \mathrm{s}]$ & Wave height $[\mathrm{m}]$ & Sea level pressure $[\mathrm{hPa}]$ & Cumulative effect \\
\hline 1 & $<10.8$ & $<1.25$ & $>1013$ & Very low \\
\hline 2 & $10.9-13.1$ & $1.25-2.5$ & $999-1013$ & Low \\
\hline 3 & $13.2-15.5$ & $2.5-3.5$ & $998-999$ & Medium \\
\hline 4 & $15.6-17.8$ & $3.5-4.5$ & $997-998$ & High \\
\hline 5 & $>17.9$ & $>4.5$ & $<997$ & Very high \\
\hline
\end{tabular}

Table 1. Classification in five classes of the three weather-marine parameters, $W S_{s}, H s_{s}$, and $S L P_{s}$, and classification of their cumulative coastal effects.

class 1 is from calm to slight wave, class 2 is moderate wave, class 3 is rough wave, classes 4 and 5 form rough to very rough. Atmospheric pressure was classified in equal intervals, starting form class 1 corresponding to high-pressure conditions, up to class 5 corresponding to low-pressure ones.

The total effect of the three classified parameters was evaluated by calculating the average values between the abovementioned classes, and consequently classified in five classes according to Table 1.

2) The second step was the calculation of the wind setup in the coastal sketches where the total effect was high, according to the following equations (Reeve et al., 2018):

$i_{w}=C_{w}\left(\frac{\rho_{a}}{\rho_{w}}\right) \frac{U_{w}^{2}}{g h}$

where $U_{w}$ is the wind speed $(\mathrm{m} / \mathrm{s}), h$ is the water depth, $\rho$ is the density of air (a) or water (w) and $C_{w}=$ air/water friction coefficient.

The maximum set-up at the downwind coast is

$\eta_{w}=i_{w} \frac{F}{2}$

where $F$ is the fetch length in metres and $\eta_{w}$ is the wind set-up in metres.

3) The last step provided the calculation of the coastal setup as the sum of wind, wave and barometric setup, along the urbanized coastal sketches with maximum values of wind setup. The aim was to evaluate the flooding during $t_{\max }$ only where the storm had destructive effects on anthropic structures. In the surf zone, the rise of the mean water level at mean depth $d_{x}$ was calculated as following (Dean and Dalrymple, 1991):

$\bar{\zeta}(x)=\bar{\zeta}_{b}+\frac{3 \gamma_{b}^{2}}{8}\left(1+\frac{3 \gamma_{b}^{2}}{8}\right)\left[d_{b}-d(x)\right]$

where $\bar{\zeta}_{b}$ is the wave setdown at the breaking depth, given by:

$180 \bar{\zeta}_{b}=-\frac{1}{16} \gamma_{b} H_{b}$ 
https://doi.org/10.5194/nhess-2021-224

Preprint. Discussion started: 26 July 2021

(c) Author(s) 2021. CC BY 4.0 License.

where $H_{b}$ is breaking wave height and $\gamma_{b}$ is the breaker index.

For spilling type breakers on dissipative beaches the assumption commonly employed is that $\gamma_{b}$ remains a fixed ratio throughout the entire surf zone:

$\gamma_{b} \approx\left(\frac{H}{d}\right)_{b}$

where $d_{b}$ is the mean depth at breaking. The breaking index was calculated by various Authors. According to Kamphuis (1991), the singificant breaking index is given by:

$\gamma_{b}=0.56 e^{3.5 m}$

where $m$ is the slope of the seabed.

The barometric setup was calculated as follow:

$190 \Delta \zeta=\frac{\Delta P_{a}}{\rho g}$

where $\Delta P_{a}$ is the pressure variation during the event.

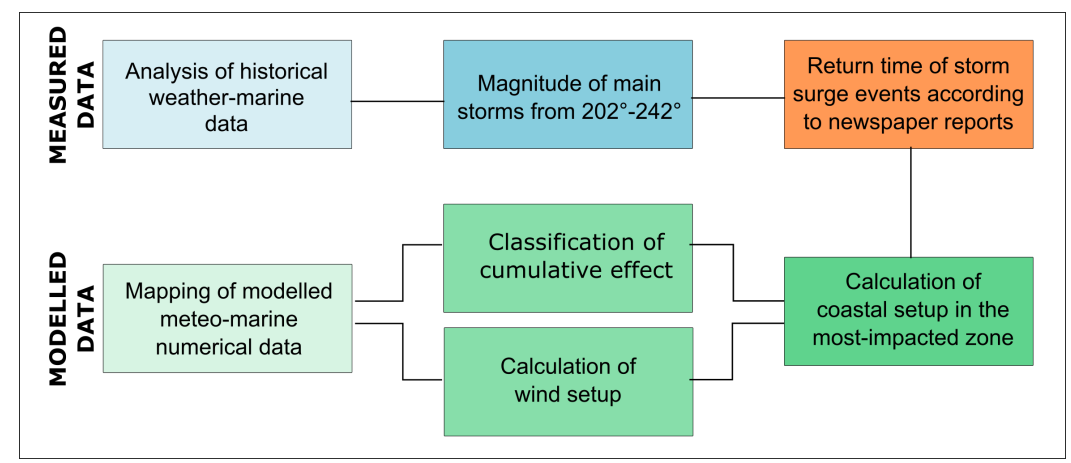

Figure 2. Workflow of the procedure applied in this study to evaluate the most impacted coastal sectors in the Gulf of Naples during the 2020-December storm. 


\section{Results}

The 2020-December storm came from SW, between $202^{\circ} \mathrm{N}$ and $242^{\circ} \mathrm{N}$. As described in the following sections, the event was characterized by anomalous wind conditions that strongly influenced effects on the coast.

\subsection{Historical wind events analysis}

An historical analysis of wind events coming from SW between 2010 and 2020 was applied to data recorded in p01 and p02 weather stations to classify the event investigated in this paper. The results reported in Figures 3 and 4 show that the most intense events with a duration higher than six hours (red points in the figures) come from the NW sector during winter months, confirming previous studies (Menna et al., 2007; Saviano et al., 2019, 2020).

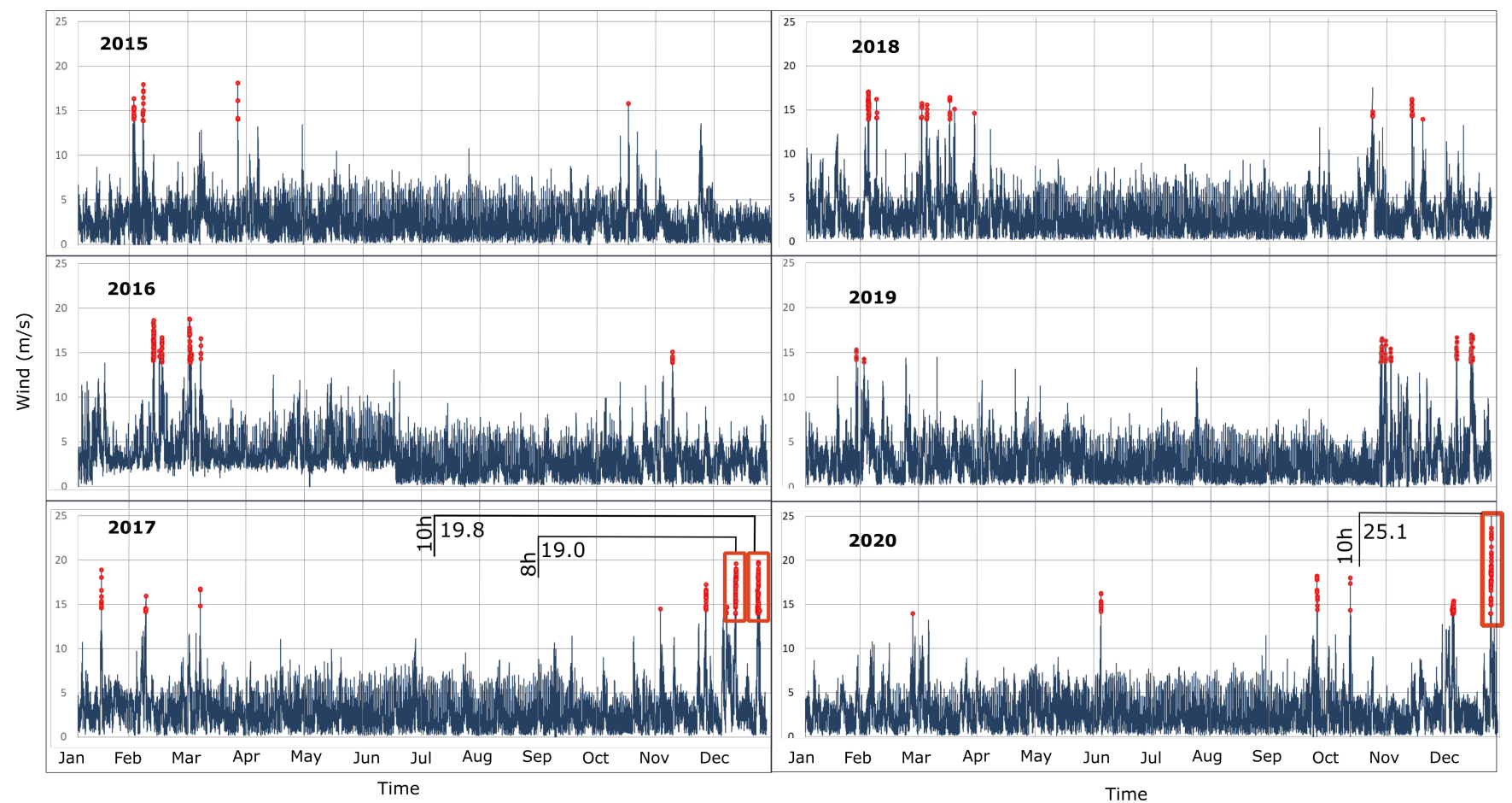

Figure 3. Graph of wind speed (m/s) between 2015 and 2020 measured by P01 weather station, red points highlight storms from $202^{\circ}-242^{\circ}$ with velocity $>13.9 \mathrm{~m} / \mathrm{s}$.

The calculation of the storm magnitude (Figure 5) shows that these events frequently occurred in December (7 out of 10). Moreover, the 2020-December storm is the most intense event occurred in the observed period, both in terms of maximum wind speed measured by p01 station $(25.1 \mathrm{~m} / \mathrm{s}$ ) and maximum duration $(11 \mathrm{~h})$ of wind speed $>13.9 \mathrm{~m} / \mathrm{s}$ ("near gale" in Beaufort scale). 


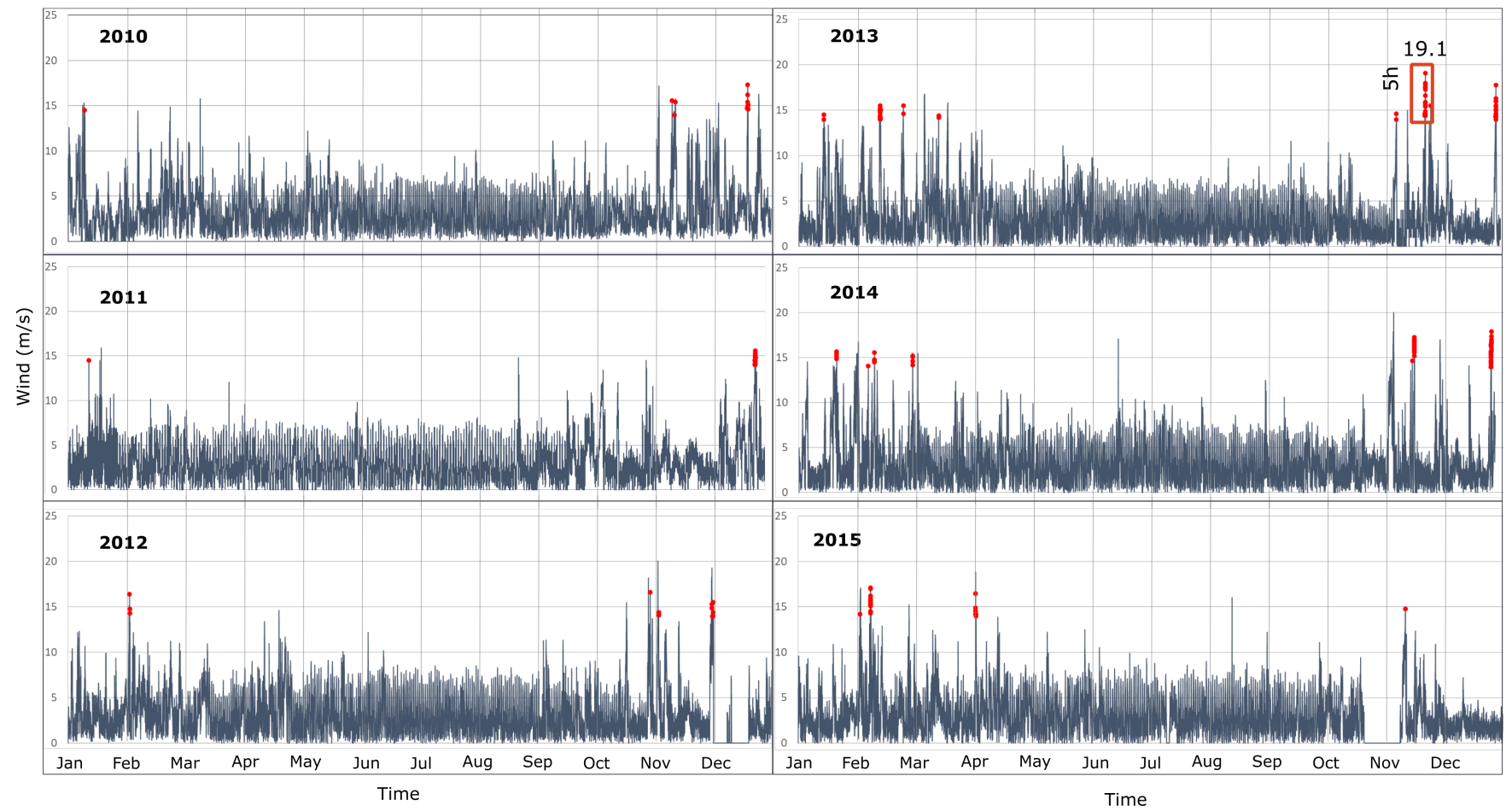

Figure 4. Graph of wind speed $(\mathrm{m} / \mathrm{s})$ between 2010 and 2015 measured by P02 weather station, red points highlight storms from $202^{\circ}-242^{\circ}$ with velocity higher than $13.9 \mathrm{~m} / \mathrm{s}$.

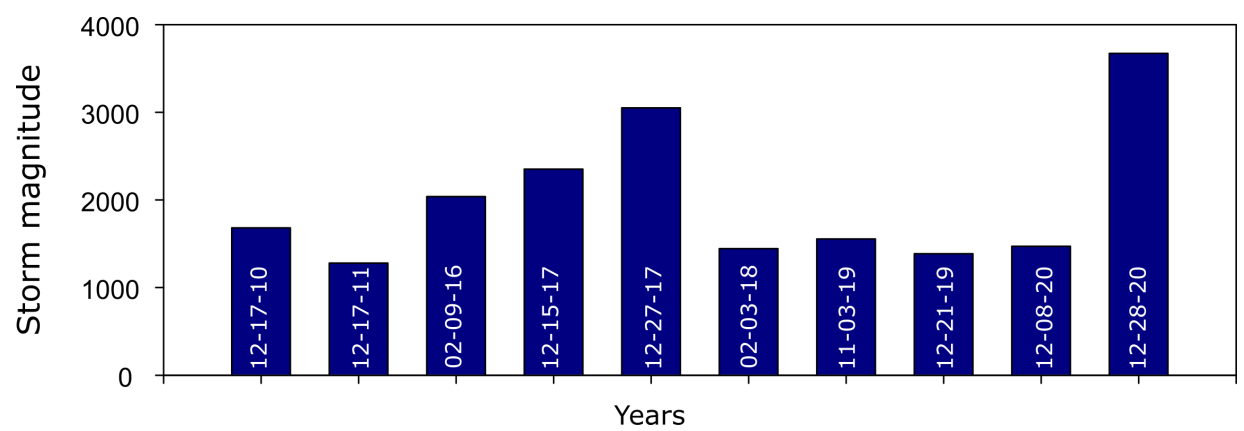

Figure 5. Magnitude of storms lasting more than 6 hours during the observation period (2010-2020) from $202^{\circ}-242^{\circ}$ directions with velocity higher than $13.9 \mathrm{~m} / \mathrm{s}$.

\subsection{Meteo-marine storm event reconstruction}

The scientific workflow described in Section 3.3 supported the reconstruction of the 2020-December storm event. As shown in Fig. 6, the study area was characterized by a low pressure front with a minimum $S L P_{s}$ value equal to $995 \mathrm{hPa}$ at $t_{\max } \pm 1 \mathrm{~h}$ during 28 December 2020. 
https://doi.org/10.5194/nhess-2021-224

Preprint. Discussion started: 26 July 2021

(c) Author(s) 2021. CC BY 4.0 License.
Natural Hazards

and Earth System

Sciences

Discussions
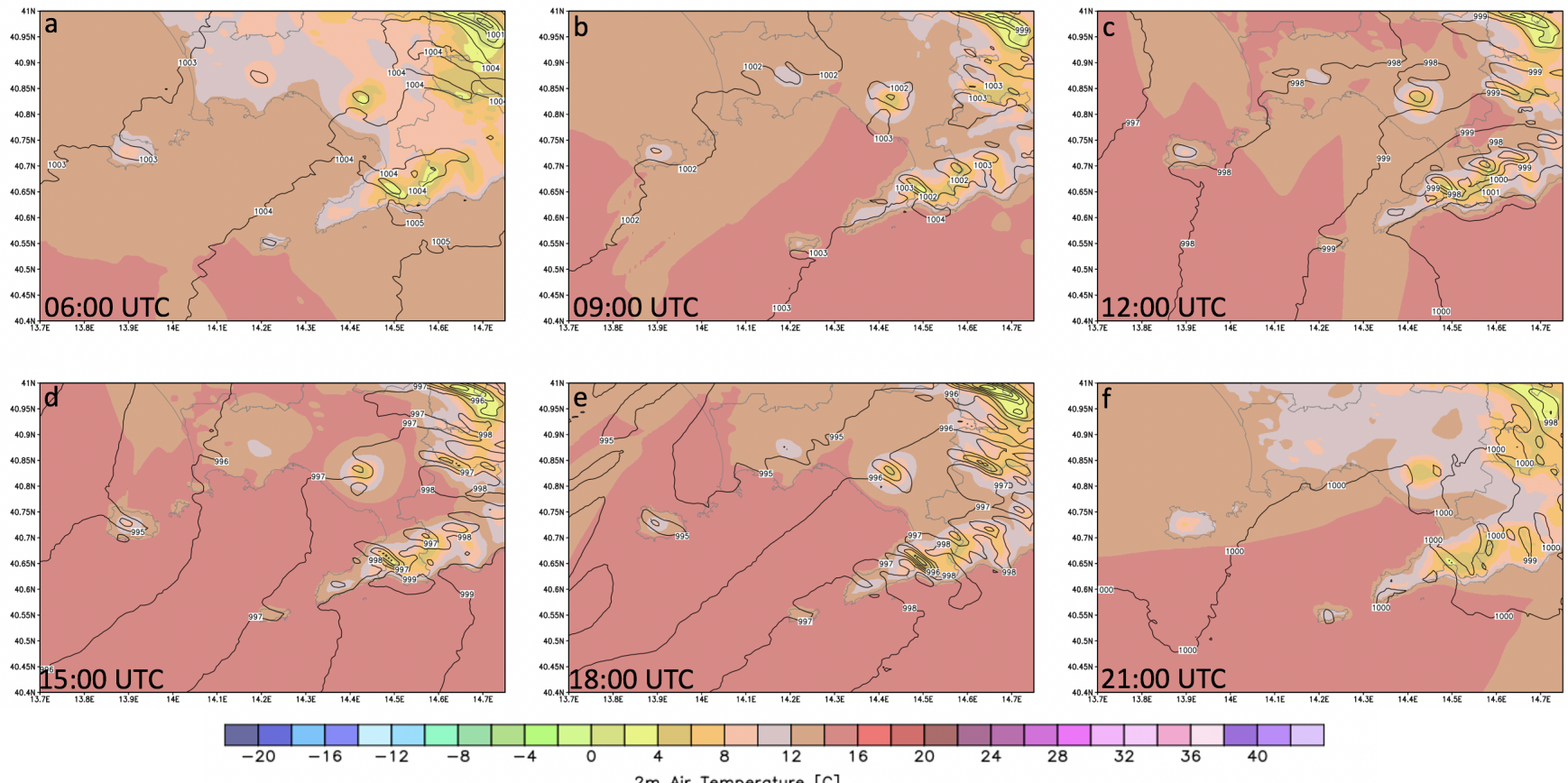

$\begin{array}{ccc}4 & 8 & 12 \\ 2 m & \text { Air } & \text { Temperature [C] }\end{array}$

Figure 6. Sea level pressure and $2 \mathrm{~m}$ air temperature simulated with WRF model on 28 December 2020 at 06 UTC (a), 09:00 UTC (b), 12:00 UTC (c), 15:00 UTC (d), 18:00 UTC and 21:00 (UTC).

On the same day, this intense atmospheric low-pressure system was accompanied by a widespread rainfall and strong winds coming from SW $\left(W S_{s}>20 \mathrm{~m} / \mathrm{s}\right)$ with gusts $>25 \mathrm{~m} / \mathrm{s}$, as shown in Figure 7 .

Moreover, the sea state at $t_{\max } \pm 1 \mathrm{~h}$ was characterized by high waves (about $4 \mathrm{~m}$ as recorded by the wave recorder b01). 

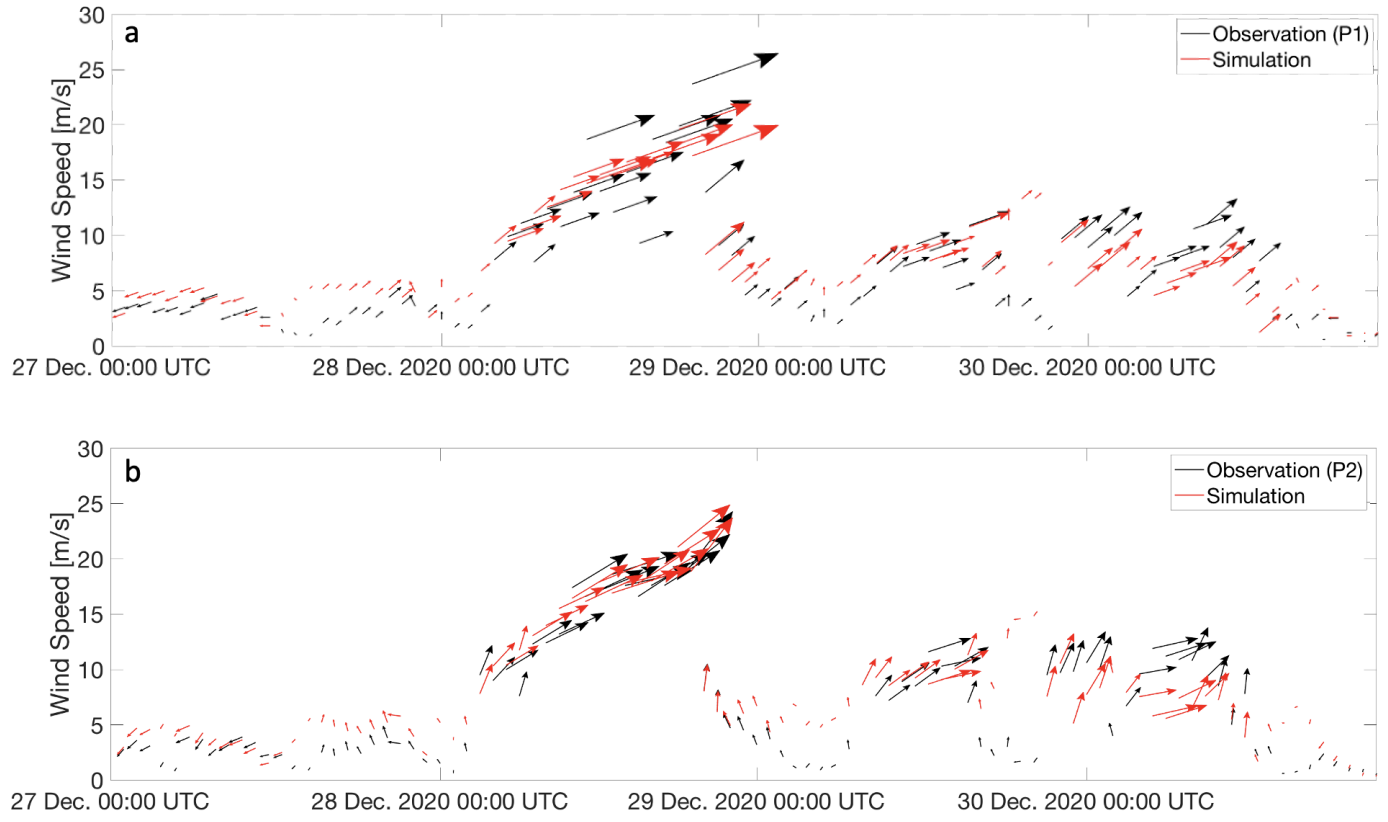

Figure 7. Comparison between wind speed and direction in-situ observations in p01 (a) and p02 (b) with the simulation results.

The combination of these and other (eg. tide level) coastal dynamic agents caused a violent storm-surge in Naples that strongly flooded the city's waterfront overnight.

The validation of the accuracy of WRF and WW3 models was done through the comparison between the hourly numerical results in the time interval 27-30 December 2020, and the data recorded by the weather and wave recording stations (p01, p02 and b01). The results evidenced that the numerical models were in good agreement with the observations. In particular, the root mean square error (RMSE) was about $0.23 \mathrm{~m}$ for the significant wave height in b01 and about $3.06 \mathrm{~m} / \mathrm{s}$ and $3.35 \mathrm{~m} / \mathrm{s}$ in case of wind speed in p01 and p02, respectively. 


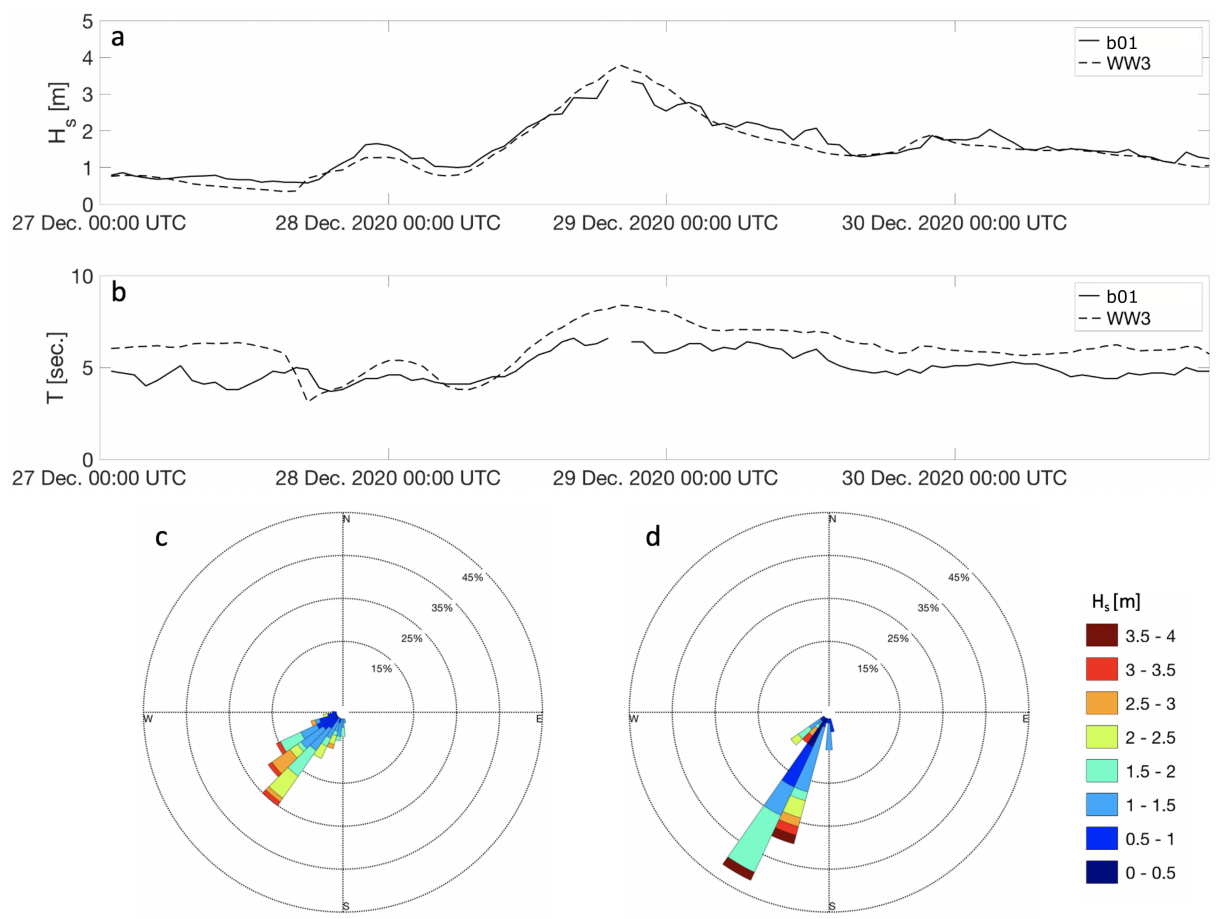

Figure 8. Comparison between in-situ wave observation and simulation about significant wave heights and period (a, b); directional distribution of the significant wave heights occurrence (c, d).

\section{Discussion of the spatial classification of storm surge effects}

The results of the spatial classification of the cumulative storm surge effects show that it was maximum (red class) along three cliffed urbanized sectors (Ischia, Capri and Sorrento Penisula) and three strongly anthropized urban low-coastal areas (Posillipo, Port of Naples and Torre Annunziata), as shown in Figure 9d.

This result can be explained through the analysis of the wind and wave spatial distribution during 28th December event in the Gulf of Naples. As a matter of fact, the wind speed in the western part of the Gulf (Figure 9a) is lower than that in the Central-Eastern part. On the contrary, the significant wave height was maximum in proximity of the islands (Capri and Ischia) with values higher than $5 \mathrm{~m}$ and between 4 and $5 \mathrm{~m}$ along the other urban exposed sectors. The spatial fetch distribution of the coastal areas, coupled with the wind speed variation, was such that the cumulative effect of the storm surge was maximum among the urbanized areas exposed to NW storms that is Naples coast (Posillipo and Port sectors) and Torre Annunziata.

However, the Naples coast (sectors 5 and 6 in Figure 10) was the most-exposed to the wind effects, as the wind setup calculation demonstrated. Consequently, the mean coastal setup was evaluated only in this sector, according to the procedure described before. In particular, the wave setup was calculated (equation 2) by using the high precision submerged DTM, obtained from a Multibeam survey of the Neapolitan area, from which the slope in shallow waters was measured. 


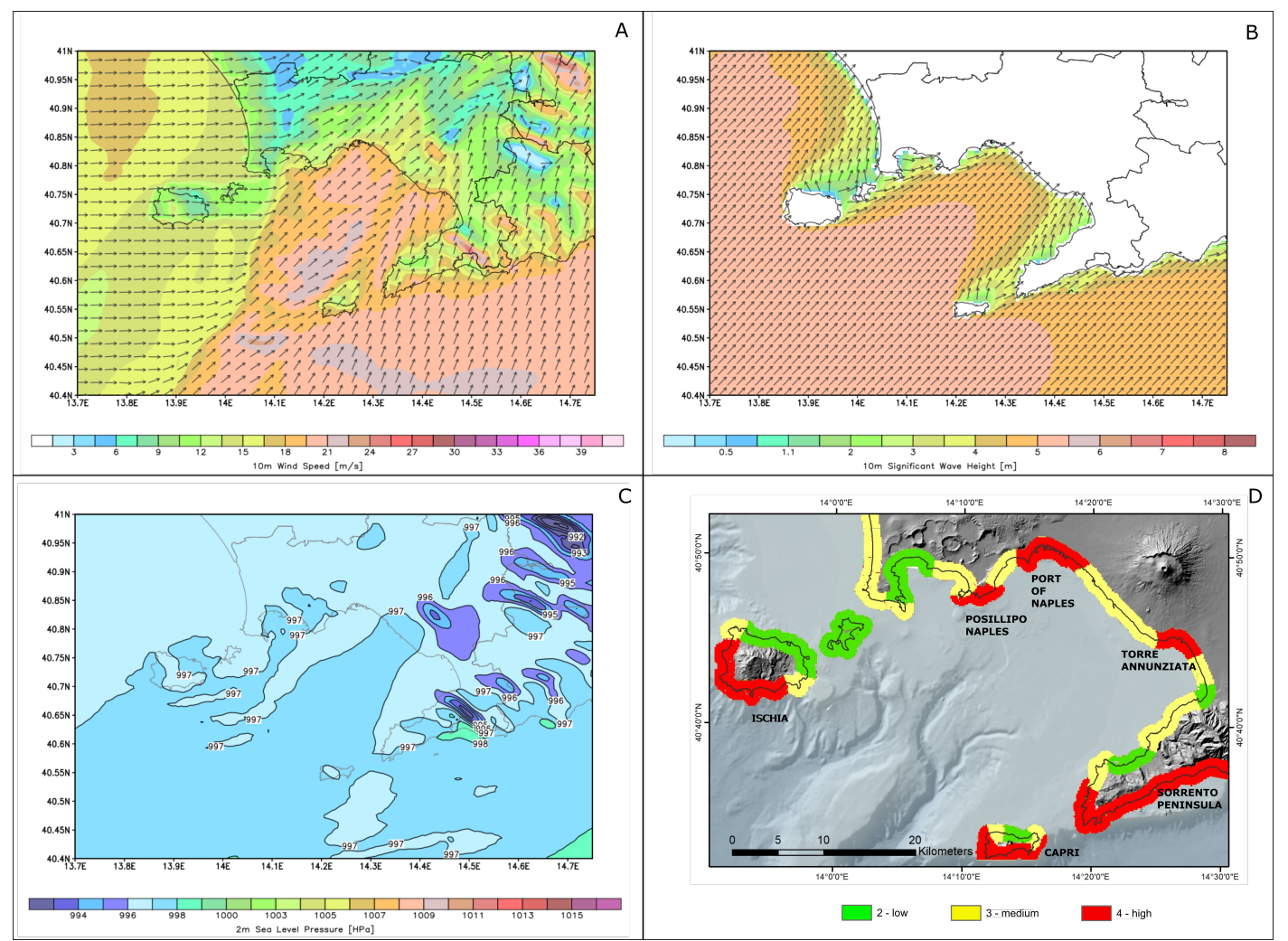

Figure 9. Maps during $t_{\max }$ of: A) wind speed; B) Significant wave height; C) Sea level pressure; D) cumulative effect of the three-modelled parameters.

As a results of the calculation (step 3 in Section 3.4), the time-averaged water-level elevation at the coastline (coastal setup) during $t_{\max }$ in the most exposed area of Naples waterfront was $1.6 \mathrm{~m}$, resulting from the sum of wind setup $(0.8 \mathrm{~m})$, wave setup $(0.3 \mathrm{~m})$, barometric setup $(0.2 \mathrm{~m})$ and water level $(0.3 \mathrm{~m})$.

The fast water level increase during $t_{\max }$ produced a twofold effect on the coast, as evidenced by video- and photo-reports (Figure 12). On one hand, a total flooding of the coastal area took place (Figure 11), on the other, wave breaking processes took place on the coastal promenade (Figure 12).

The flooding produced several destructive effects that interested the whole coastal sector, as shown in Figures 13, including a XIV century castle (Castel dell'Ovo, Figure 13e,f). In the touristic city area between via Caracciolo and Castel dell'Ovo, the main damages interested both commercial activities and archaeological structures. In particular, a part of the promenade was dismantled, together with the bungalows of some restaurants, and some shop windows (Figure 13b). Regarding the cultural heritage, the total destruction of the Bourbonic pier occurred (Figure 13h) and the dismantling of the nineteenth-century pavement on the outside of Castel dell'Ovo. The main damages into the Port were related to the military infrastructures located on the San Vincenzo pier (Figure 13c). 
https://doi.org/10.5194/nhess-2021-224

Preprint. Discussion started: 26 July 2021

(c) Author(s) 2021. CC BY 4.0 License.
Natural Hazards and Earth System Sciences

Discussions

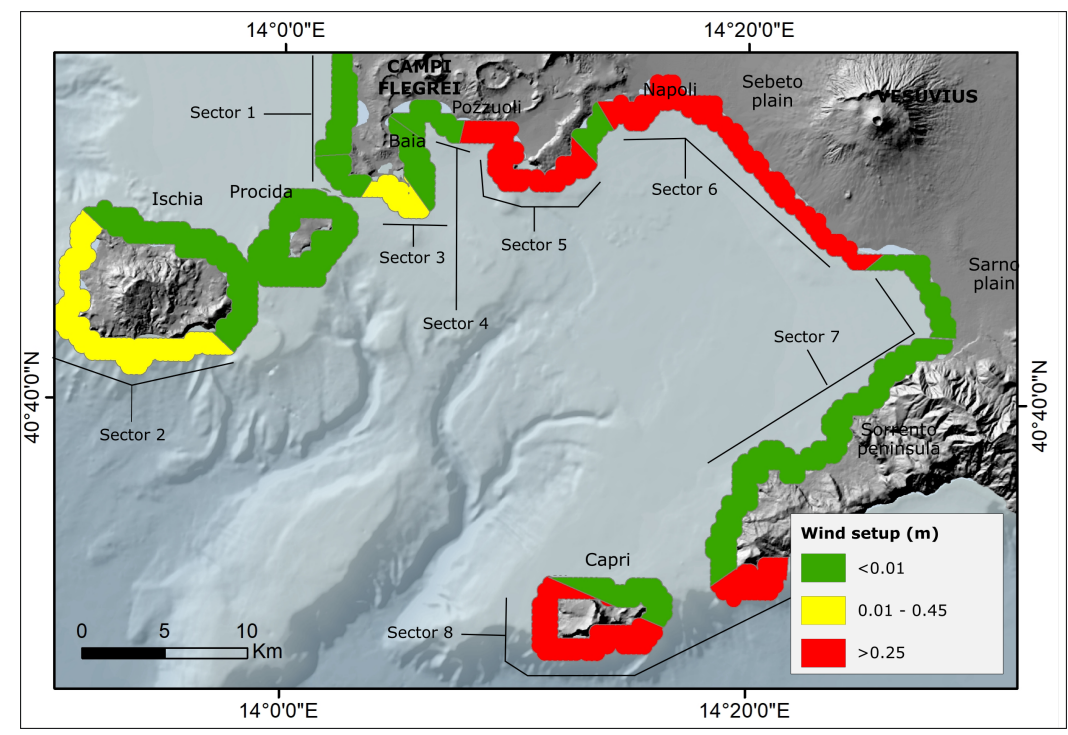

Figure 10. Wind setup along the coast of Gulf of Naples during $t_{\max }$.

The return period of this event was evaluated through the analysis of historical archives of local newspapers. According to the last 100 year chronicles, based on similar damage records, the 2020-December storm surge is a weather-marine event with a very high return period. In fact, the only past event with similar destructive effects occurred on $28^{\text {th }}$ December 1927 , as described by local newspapers (Figure 14). 

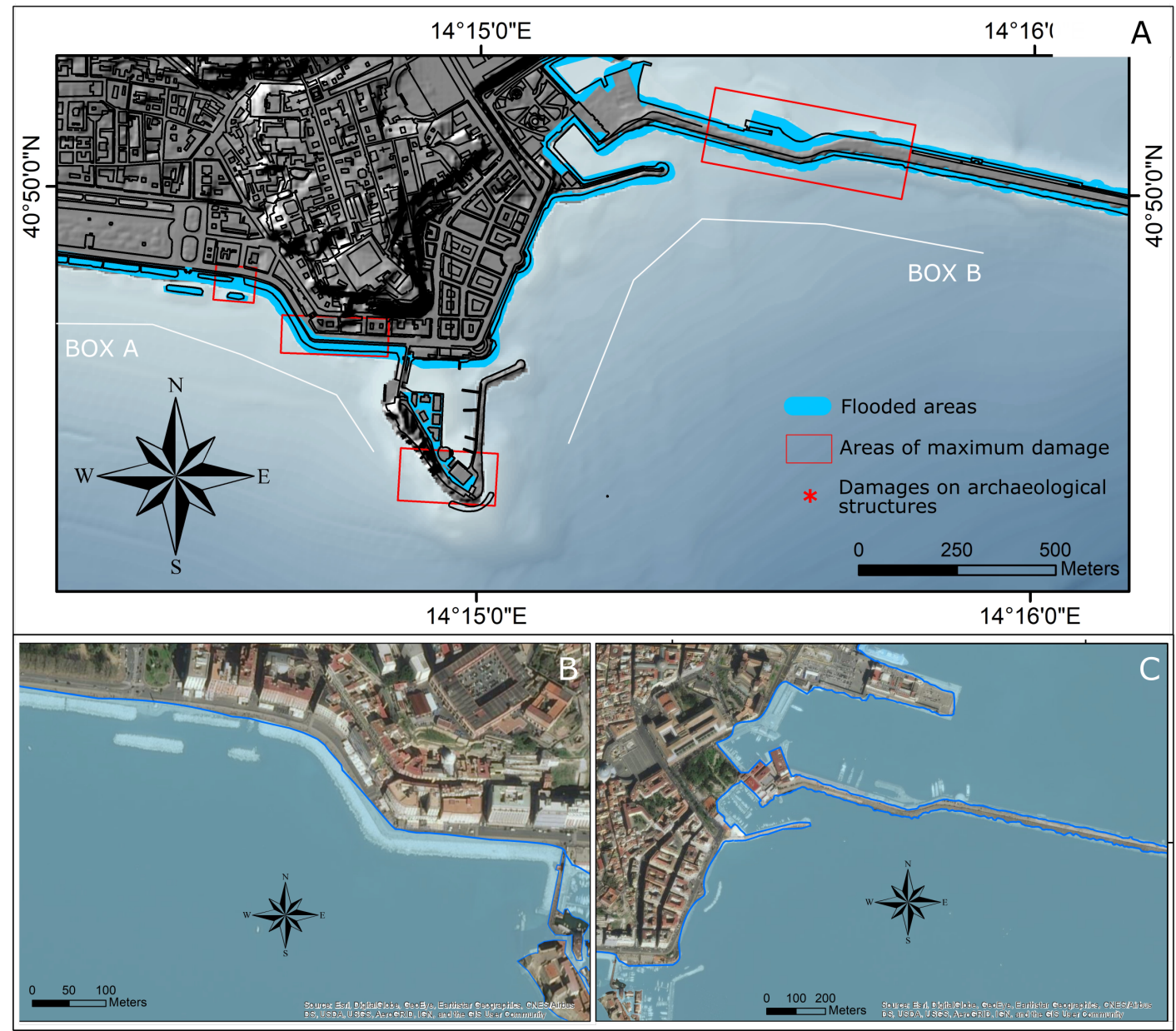

Figure 11. A) Surge in the coastal area with maximum setup values (Naples city centre) during the storm event; Zoom of flooded areas in B) W sector and C) E sector.

\section{Conclusions}

The marine storm of 28th December 2020 that affected the Gulf of Naples represented an outstanding storm associated with the persistence of wind speed up to $90 \mathrm{~km} / \mathrm{h}$ and low-pressure conditions $(997 \mathrm{hPa})$. This caused a significant surge with a local increase of about $1.6 \mathrm{~m}$ during the peak of the event. The anomalous water level rise provoked the flooding of wide coastal areas of Naples city, with catastrophic effects on port infrastructures, urban facilities and cultural heritage. The very high intensity of this event was testified also by the analysis of historical chronicles that identified only one storm with similar destructive effects in December 1927. The numerical characterization of this SW-storm, based on the high spatial resolution model, allowed the detection of the most-exposed coastal sectors in the Gulf, according to the first step of the proposed procedure. On the other hand, this expedited procedure resulted in an efficient way to measure the effects of this event on the urbanized areas among 
https://doi.org/10.5194/nhess-2021-224

Preprint. Discussion started: 26 July 2021

(c) Author(s) 2021. CC BY 4.0 License.
Natural Hazards

and Earth System

Sciences

Discussions
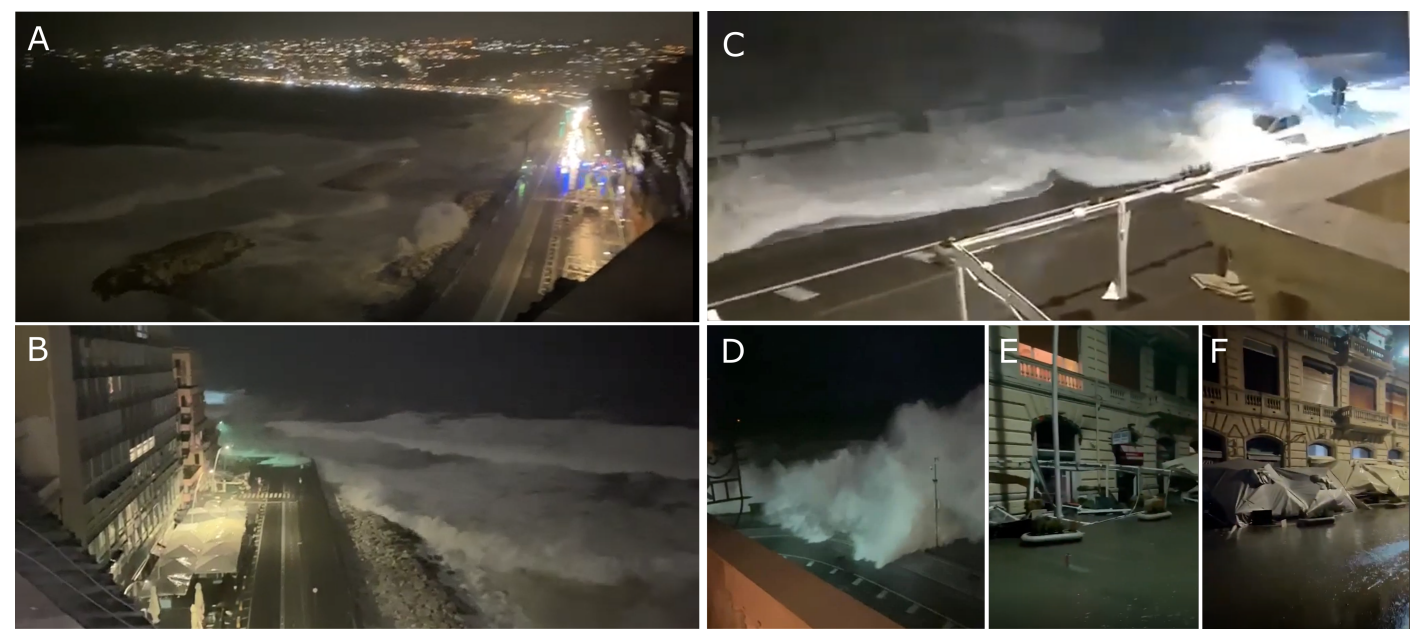

Figure 12. Photos of: A), B), C) and D) Storm surge in the coastal area with maximum setup values (Naples city centre); E) and F) Damages on structures during the event

the most-exposed sectors. The main result was the definition of threshold values for wind speed and duration, coupled with atmospheric pressure and medium wave height, which could be used as an alert for future similar events coming from the fourth quadrant. This fast procedure applied to data from the weather-marine forecasting networks can become an operative tool for local authorities asked to apply protective actions to human activities. Consequently, the approach proposed in this study has the aim to limit the damages of extreme events, through the two following actions, that is the preliminary detection of the destructive storms in time and space and the implementation of fast procedures for alerting. In addition, in the framework of the ongoing climate change, the creation of high-resolution databases of the main weather-marine characteristics of extreme events sounds strategic for planning mitigation actions and coastal zone management in strongly urbanized areas. 


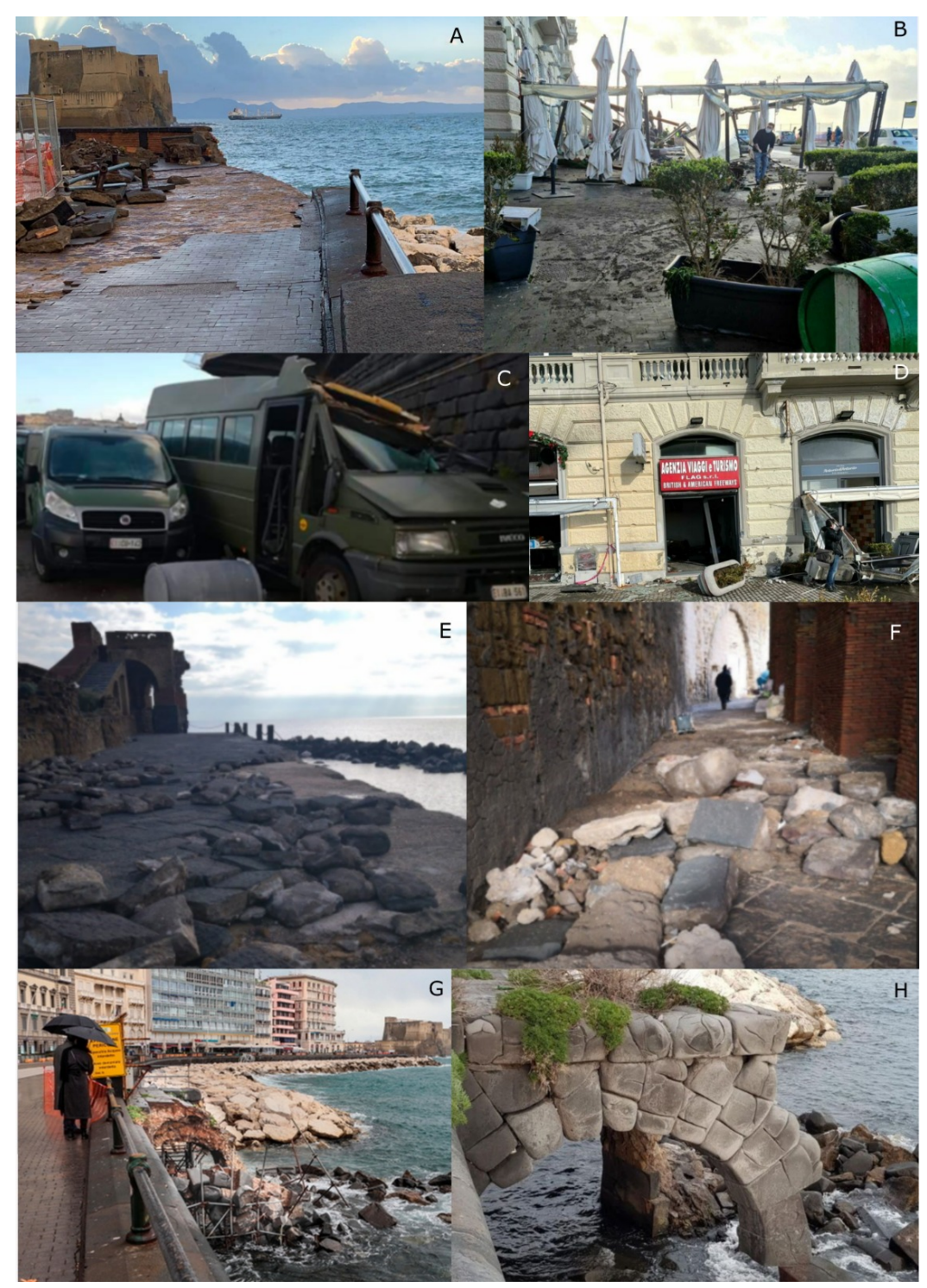

Figure 13. Photos of the main damages on structures after the event: A) promenade destroyed with collapsed parapet; B) damage on external structures of some restaurants; C) damage on military infrastructures; D) shattered shop windows; E) and F) Castel dell'Ovo after the event; G) Bourbon pier after the event; H) Bourbon pier before the event.

\section{Author contributions.}

Conceptualization: P.A. and G.B.; Data curation: G.M. and D.D.L., Formal analysis: G.M. and G.B.; Methodology: G.B. G.M and D.D.L.; Software: D.D.L.; Supervision: P.A., G.A. and G.B; Validation: D.D.L. and G.M.; Visualization: D.D.L and G.M.; Writing - original draft preparation: G.M., G.B. and D.D.L.; Writing - review \& editing: G.M., G.B., D.D.L. and G.A. 
https://doi.org/10.5194/nhess-2021-224

Preprint. Discussion started: 26 July 2021

(c) Author(s) 2021. CC BY 4.0 License.

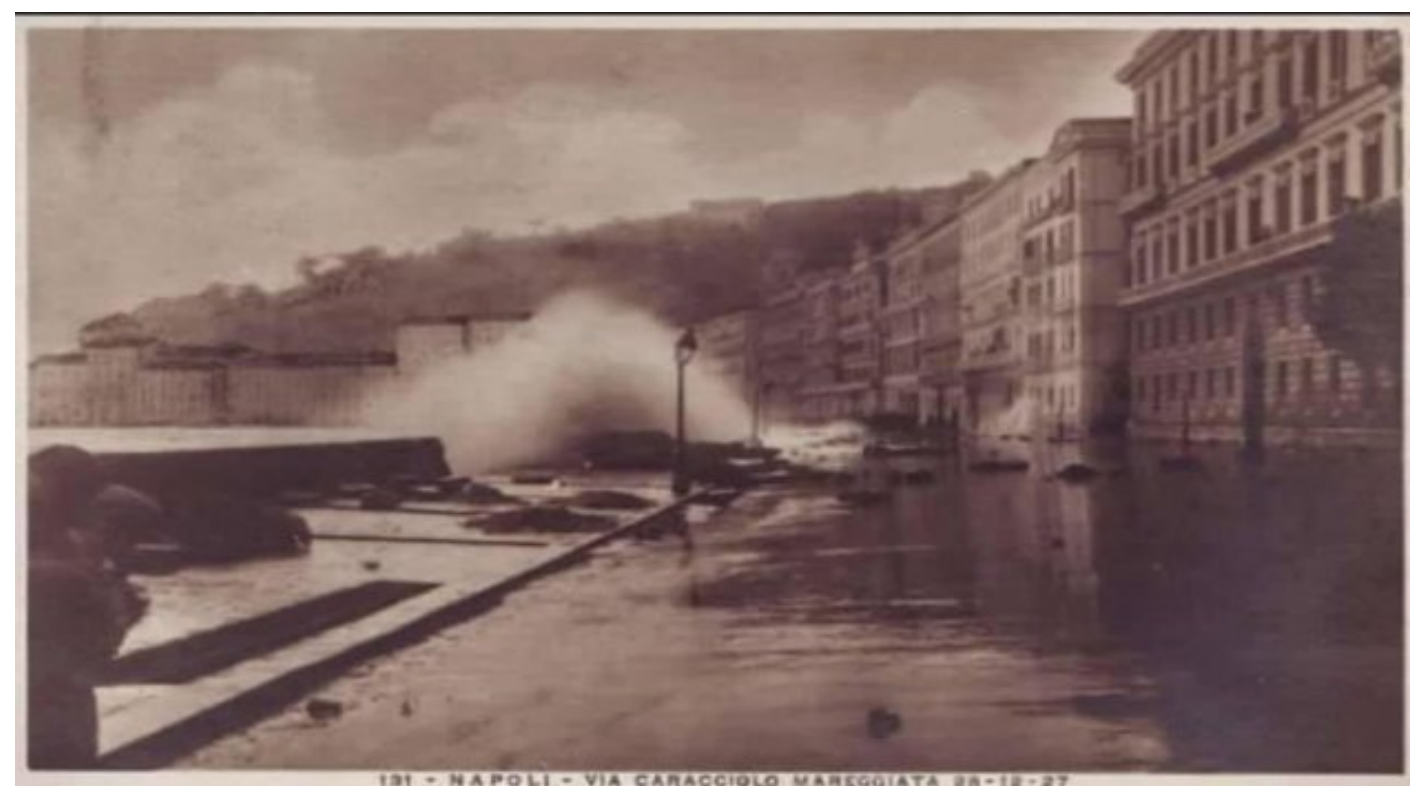

Figure 14. Historical photo of 1927-storm that impacted and destroyed via Caracciolo, Naples (from il Mattino newspaper).

Acknowledgements. This work is a contribution to the Andalusia PAI research Group RNM-328. 


\section{References}

Amarouche, K., Akpınar, A., Cakmak, R. E., Houma, F., and Bachari, N. E. I.: Assessment of storm events along the Algiers coast and their potential impacts, Ocean Engineering, 210, 107 432, 2020.

Amores, A., Marcos, M., Carrió, D. S., and Gómez-Pujol, L.: Coastal impacts of Storm Gloria (January 2020) over the north-western Mediterranean, Natural Hazards and Earth System Sciences, 20, 1955-1968, 2020.

Anfuso, G., Rangel-Buitrago, N., Cortés-Useche, C., Iglesias Castillo, B., and Gracia, F.: Characterization of storm events along the Gulf of Cadiz (eastern central Atlantic Ocean), International Journal of Climatology, 36, 3690-3707, 2016.

Ascione, A., Aucelli, P. P., Cinque, A., Di Paola, G., Mattei, G., Ruello, M., Russo Ermolli, E., Santangelo, N., and Valente, E.: Geomorphology of Naples and the Campi Flegrei: human and natural landscapes in a restless land, Journal of Maps, pp. 1-11, 2020.

Aucelli, P., Cinque, A., Giordano, F., and Mattei, G.: A geoarchaeological survey of the marine extension of the Roman archaeological site Villa del Pezzolo, Vico Equense, on the Sorrento Peninsula, Italy, Geoarchaeology, 31, 244-252, $2016 \mathrm{.}$.

Aucelli, P., Cinque, A., Mattei, G., and Pappone, G.: Historical sea level changes and effects on the coasts of Sorrento Peninsula (Gulf of Naples): New constrains from recent geoarchaeological investigations, Palaeogeography, Palaeoclimatology, Palaeoecology, 463, 112$125,2016 b$.

Aucelli, P., Cinque, A., Mattei, G., Pappone, G., and Stefanile, M.: Coastal landscape evolution of Naples (Southern Italy) since the Roman period from archaeological and geomorphological data at Palazzo degli Spiriti site, Quaternary International, 483, 23-38, 2018a.

Aucelli, P., Cinque, A., Mattei, G., Pappone, G., and Rizzo, A.: Studying relative sea level change and correlative adaptation of coastal structures on submerged Roman time ruins nearby Naples (southern Italy), Quaternary International, 501, 328-348, 2019.

Aucelli, P. P., Cinque, A., Mattei, G., and Pappone, G.: Late Holocene landscape evolution of the gulf of Naples (Italy) inferred from geoarchaeological data, Journal of Maps, 13, 300-310, 2017.

Aucelli, P. P., Cinque, A., Mattei, G., Pappone, G., and Stefanile, M.: First results on the coastal changes related to local sea level variations along the Puteoli sector (Campi Flegrei, Italy) during the historical times, Alp. Mediterr. Quat, 31, 3-16, $2018 \mathrm{~b}$.

Aucelli, P. P., Mattei, G., Caporizzo, C., Cinque, A., Troisi, S., Peluso, F., Stefanile, M., and Pappone, G.: Ancient coastal changes due to ground movements and human interventions in the Roman Portus Julius (Pozzuoli Gulf, Italy): Results from photogrammetric and direct surveys, Water, 12, 658, 2020.

Aucelli, P. P., Mattei, G., Caporizzo, C., Cinque, A., Amato, L., Stefanile, M., and Pappone, G.: Multi-proxy analysis of relative sea-level and paleoshoreline changes during the last 2300 years in the Campi Flegrei caldera, Southern Italy, Quaternary International, 2021.

Benassai, G., De Maio, A., and Sansone, E.: Altezze e periodi delle onde significative nel Golfo di Napoli dall'aprile 1986 al giugno 1987 , Ann. IUN, 61, 3-9, 1994.

Biolchi, S., Denamiel, C., Devoto, S., Korbar, T., Macovaz, V., Scicchitano, G., Vilibić, I., and Furlani, S.: Impact of the October 2018 storm Vaia on coastal boulders in the northern Adriatic Sea, Water, 11, 2229, 2019.

Buonocore, B., Sansone, E., and Zambardino, G.: Rilievi ondametrici nel Golfo di Napoli, Ann. IUN, 67, 203-211, 2003.

Castagno, P., de Ruggiero, P., Pierini, S., Zambianchi, E., De Alteris, A., De Stefano, M., and Budillon, G.: Hydrographic and dynamical characterisation of the Bagnoli-Coroglio Bay (Gulf of Naples, Tyrrhenian Sea), Chemistry and Ecology, 36, 598-618, 2020. The October 29, 2018 storm in Northern Italy-an exceptional event and its modeling, Progress in oceanography, 178,102 178, 2019. Cinque, A.: La trasgressione versiliana nella Piana del Sarno (Campania), Geografia Fisica e Dinamica Quaternaria, 14, 63-71, 1991. 
Cinque, A., Irollo, G., Romano, P., Ruello, M. R., Amato, L., and Giampaola, D.: Ground movements and sea level changes in urban areas: 5000 years of geological and archaeological record from Naples (Southern Italy), Quaternary International, 232, 45-55, 2011.

310 Costas, S., Ferreira, O., and Martinez, G.: Why do we decide to live with risk at the coast?, Ocean \& Coastal Management, 118, 1-11, 2015. de Ruggiero, P., Napolitano, E., Iacono, R., and Pierini, S.: A high-resolution modelling study of the circulation along the Campania coastal system, with a special focus on the Gulf of Naples, Continental Shelf Research, 122, 85-101, 2016.

de Ruggiero, P., Napolitano, E., Iacono, R., Pierini, S., and Spezie, G.: A baroclinic coastal trapped wave event in the Gulf of Naples (Tyrrhenian Sea), Ocean Dynamics, 68, 1683-1694, 2018.

315 Dean, R. G. and Dalrymple, R. A.: Water wave mechanics for engineers and scientists, vol. 2, World Scientific Publishing Company, 1991.

Di Luccio, D., Benassai, G., Budillon, G., Mucerino, L., Montella, R., and Pugliese Carratelli, E.: Wave run-up prediction and observation in a micro-tidal beach, Natural Hazards and Earth System Sciences, 18, 2841-2857, 2018a.

Di Luccio, D., Benassai, G., Di Paola, G., Rosskopf, C. M., Mucerino, L., Montella, R., and Contestabile, P.: Monitoring and modelling coastal vulnerability and mitigation proposal for an archaeological site (Kaulonia, Southern Italy), Sustainability, 10, 2017, 2018b.

Di Luccio, D., Benassai, G., de Stefano, M., and Montella, R.: Evidences of atmospheric pressure drop and sea level alteration in the Ligurian Sea, in: 2019 IMEKO TC19 International Workshop on Metrology for the Sea: Learning to Measure Sea Health Parameters, MetroSea 2019, pp. 22-27, 2020a.

Di Luccio, D., Benassai, G., Mucerino, L., Montella, R., Conversano, F., Pugliano, G., Robustelli, U., and Budillon, G.: Characterization of beach run-up patterns in Bagnoli bay during ABBACO project, Chemistry and Ecology, 36, 619-636, $2020 \mathrm{~b}$.

Di Luccio, D., Buono, A., Corcione, V., Migliaccio, M., and Benassai, G.: An integrated approach of in-situ data, remote sensing measurements and numerical simulations to study storm events in the Ligurian Sea, pp. 28-33, 2021.

Dobrynin, M., Murawsky, J., and Yang, S.: Evolution of the global wind wave climate in CMIP5 experiments, Geophysical Research Letters, 39, 2012.

Esnard, A.-M., Brower, D., and Bortz, B.: Coastal Hazards and the Built Environment on Barrier Islands: A Retrospective View of Nags Head $n$ the Late 1990s, Coastal Management, 29, 53-72, 2001.

Fedele, L., Morra, V., Perrotta, A., Scarpati, C., Putignano, M., Orrù, P., Schiattarella, M., Aiello, G., D’Argenio, B., and Conforti, A.: Note illustrative della Carta Geologica d'Italia alla scala 1: 50.000, foglio 465 Isola di Procida, Istituto Superiore per la Protezione e la Ricerca Ambientale, Servizio Geologico d'Italia, 1, 204, 2015.

Ferrando, I., Brandolini, P., Federici, B., Lucarelli, A., Sguerso, D., Morelli, D., and Corradi, N.: Coastal Modification in Relation to Sea Storm Effects: Application of 3D Remote Sensing Survey in Sanremo Marina (Liguria, NW Italy), Water, 13, $1040,2021$.

Godschalk, D. R., Norton, R., Richardson, C., and Salvesen, D.: Avoiding coastal hazard areas: Best state mitigation practices, Environmental Geosciences, 7, 13-22, 2000.

Gulev, S. K. and Grigorieva, V.: Last century changes in ocean wind wave height from global visual wave data, Geophysical Research Letters, $31,2004$.

Iannace, A., Merola, D., Perrone, V., Amato, A., Cinque, A., Santacroce, R., Sbrana, A., Sulpizio, R., Budillon, F., Conforti, A., et al.: Note illustrative della carta geologica d'Italia alla scala 1: 50.000 Foglio 466-485 Sorrento-Termini, Servizio Geologico d'Italia, ISPRA, p. 204, 2015.

Isaia, R., Iannuzzi, E., Sbrana, A., and Marianelli, P.: Note Illustrative della Carta Geologica d'Italia alla scala 1: 50.000, Foglio 446-447 Napoli (aree emerse), 2018. 
Jiménez, J., Sanuy, M., Ballesteros, C., and Valdemoro, H.: The Tordera Delta, a hotspot to storm impacts in the coast northwards of Barcelona (NW Mediterranean), Coastal Engineering, 134, 148-158, 2018.

Jiménez, J. A., Sancho-García, A., Bosom, E., Valdemoro, H. I., and Guillén, J.: Storm-induced damages along the Catalan coast (NW Mediterranean) during the period 1958-2008, Geomorphology, 143, 24-33, 2012.

Kamphuis, J.: Wave transformation, Coastal Engineering, 15, 173-184, 1991.

Lionello, P. and Scarascia, L.: The relation of climate extremes with global warming in the Mediterranean region and its north versus south contrast, Regional Environmental Change, 20, 1-16, 2020.

Lira-Loarca, A., Cobos, M., Losada, M. Á., and Baquerizo, A.: Storm characterization and simulation for damage evolution models of maritime structures, Coastal Engineering, 156, $103620,2020$.

Mattei, G., Troisi, S., Aucelli, P. P., Pappone, G., Peluso, F., and Stefanile, M.: Sensing the submerged landscape of Nisida Roman Harbour in the Gulf of Naples from integrated measurements on a USV, Water, 10, 1686, 2018.

Mattei, G., Aucelli, P. P., Caporizzo, C., Rizzo, A., and Pappone, G.: New geomorphological and historical elements on morpho-evolutive trends and relative sea-level changes of naples coast in the last 6000 years, Water, 12, 2651, 2020.

Menna, M., Mercatini, A., Uttieri, M., Buonocore, B., and Zambianchi, E.: Wintertime transport processes in the Gulf of Naples investigated by HF radar measurements of surface currents, Il nuovo cimento C, 30, 605-622, 2007.

Meucci, A., Young, I. R., Aarnes, O. J., and Breivik, Ø.: Comparison of wind speed and wave height trends from twentieth-century models and satellite altimeters, Journal of Climate, 33, 611-624, 2020.

Milia, A.: The stratigraphic signature of volcanism off Campi Flegrei (Bay of Naples, Italy), Geological Society of America Special Papers, 464, 155-170, 2010.

Milia, A. and Torrente, M.: Tectonics and stratigraphic architecture of a peri-Tyrrhenian half-graben (Bay of Naples, Italy), Tectonophysics, 315, 301-318, 1999.

Milia, A. and Torrente, M.: Late-Quaternary volcanism and transtensional tectonics in the Bay of Naples, Campanian continental margin, Italy, Mineralogy and Petrology, 79, 49-65, 2003.

Molina, R., Manno, G., Lo Re, C., Anfuso, G., and Ciraolo, G.: Storm energy flux characterization along the Mediterranean coast of Andalusia (Spain), Water, 11, 509, 2019.

Molina, R., Manno, G., Re, C. L., Anfuso, G., and Ciraolo, G.: A Methodological Approach to Determine Sound Response Modalities to Coastal Erosion Processes in Mediterranean Andalusia (Spain), Journal of Marine Science and Engineering, 8, $154,2020$.

Montella, R., Di Luccio, D., and Kosta, S.: DagOn*: Executing direct acyclic graphs as parallel jobs on anything, in: 2018 IEEE/ACM Workflows in Support of Large-Scale Science (WORKS), pp. 64-73, IEEE, 2018.

Montella, R., Di Luccio, D., Ciaramella, A., and Foster, I.: StormSeeker: A Machine-Learning-Based Mediterranean Storm Tracer, in: International Conference on Internet and Distributed Computing Systems, pp. 444-456, Springer, 2019.

Morucci, S., Picone, M., Nardone, G., and Arena, G.: Tides and waves in the Central Mediterranean Sea, Journal of Operational Oceanography, 9, s10-s17, 2016.

Pappone, G., Aucelli, P. P., Mattei, G., Peluso, F., Stefanile, M., and Carola, A.: A detailed reconstruction of the Roman landscape and the submerged archaeological structure at “Castel dell'Ovo islet”(Naples, Southern Italy), Geosciences, 9, 170, 2019.

Powers, J. G., Klemp, J. B., Skamarock, W. C., Davis, C. A., Dudhia, J., Gill, D. O., Coen, J. L., Gochis, D. J., Ahmadov, R., Peckham, S. E., et al.: The weather research and forecasting model: Overview, system efforts, and future directions, Bulletin of the American Meteorological Society, 98, 1717-1737, 2017. 
Reeve, D., Chadwick, A., and Fleming, C.: Coastal engineering: processes, theory and design practice, CRC Press, 2018.

Reguero, B. G., Losada, I. J., and Méndez, F. J.: A recent increase in global wave power as a consequence of oceanic warming, Nature communications, 10, 1-14, 2019.

Romano, P., Di Vito, M., Giampaola, D., Cinque, A., Bartoli, C., Boenzi, G., Detta, F., Di Marco, M., Giglio, M., Iodice, S., et al.: Intersection of exogenous, endogenous and anthropogenic factors in the Holocene landscape: A study of the Naples coastline during the last 6000 years, Quaternary International, 303, 107-119, 2013.

Sánchez-Gallegos, D. D., Di Luccio, D., Gonzalez-Compean, J., and Montella, R.: A Microservice-Based Building Block Approach for Scientific Workflow Engines: Processing Large Data Volumes with DagOnStar, in: 2019 15th International Conference on Signal-Image Technology \& Internet-Based Systems (SITIS), pp. 368-375, IEEE, 2019a.

Sánchez-Gallegos, D. D., Di Luccio, D., Gonzalez-Compean, J. L., and Montella, R.: Internet of Things orchestration using DagOn* workflow engine, in: 2019 IEEE 5th World Forum on Internet of Things (WF-IoT), pp. 95-100, IEEE, 2019b.

Sánchez-Gallegos, D. D., Di Luccio, D., Kosta, S., Gonzalez-Compean, J., and Montella, R.: An efficient pattern-based approach for workflow supporting large-scale science: The DagOnStar experience, Future Generation Computer Systems, 122, 187-203, 2021.

Santacroce, R., Sbrana, A., Andronico, A., Arrighi, S., Benvenuti, E., Cioni, R., Di Vito, M., Gurioli, L., Luperini, W., Marianelli, P., et al.: Carta geologica del Vesuvio, 1: 15000 Progetto CARG, Servizio Geologico Nazionale, CNR, 2003.

Sanuy, M., Duo, E., Jäger, W. S., Ciavola, P., and Jiménez, J. A.: Linking source with consequences of coastal storm impacts for climate change and risk reduction scenarios for Mediterranean sandy beaches, Natural Hazards and Earth System Sciences, 18, 1825-1847, 2018.

Saviano, S., Kalampokis, A., Zambianchi, E., and Uttieri, M.: A year-long assessment of wave measurements retrieved from an HF radar network in the Gulf of Naples (Tyrrhenian Sea, Western Mediterranean Sea), Journal of Operational Oceanography, 12, 1-15, 2019.

Saviano, S., Cianelli, D., Zambianchi, E., Conversano, F., and Uttieri, M.: An integrated reconstruction of the multiannual wave pattern in the Gulf of Naples (South-Eastern Tyrrhenian Sea, Western Mediterranean Sea), Journal of Marine Science and Engineering, 8, $372,2020$.

Skamarock, W. C., Klemp, J. B., and Dudhia, J.: Prototypes for the WRF (Weather Research and Forecasting) model, in: Preprints, Ninth Conf. Mesoscale Processes, J11-J15, Amer. Meteorol. Soc., Fort Lauderdale, FL, 2001.

Tsai, C.-H. and Chen, C.-W.: The establishment of a rapid natural disaster risk assessment model for the tourism industry, Tourism management, 32, 158-171, 2011.

Uttieri, M., Cianelli, D., Nardelli, B. B., Buonocore, B., Falco, P., Colella, S., and Zambianchi, E.: Multiplatform observation of the surface circulation in the Gulf of Naples (Southern Tyrrhenian Sea), Ocean Dynamics, 61, 779-796, 2011.

410 Vacchi, M., Marriner, N., Morhange, C., Spada, G., Fontana, A., and Rovere, A.: Multiproxy assessment of Holocene relative sea-level changes in the western Mediterranean: Sea-level variability and improvements in the definition of the isostatic signal, Earth-Science Reviews, 155, 172-197, 2016.

Van Westen, C. J.: Remote sensing and GIS for natural hazards assessment and disaster risk management, Treatise on geomorphology, 3, 259-298, 2013.

415 Vieira, F., Cavalcante, G., and Campos, E.: Analysis of wave climate and trends in a semi-enclosed basin (Persian Gulf) using a validated SWAN model, Ocean Engineering, 196, 106 821, 2020.

Williams, A., Rangel-Buitrago, N., Pranzini, E., and Anfuso, G.: The management of coastal erosion, Ocean \& coastal management, 156, 4-20, 2018.

Young, I. R. and Ribal, A.: Multiplatform evaluation of global trends in wind speed and wave height, Science, 364, 548-552, 2019. 